University of Nebraska - Lincoln

DigitalCommons@University of Nebraska - Lincoln

2005

Hydrologic properties of coal beds in the Powder River Basin,

Montana I. Geophysical log analysis

Roger H. Morin

Denver Federal Center, roger.morin49@gmail.com

Follow this and additional works at: https://digitalcommons.unl.edu/usgsstaffpub

Part of the Earth Sciences Commons

Morin, Roger H., "Hydrologic properties of coal beds in the Powder River Basin, Montana I. Geophysical log analysis" (2005). USGS Staff -- Published Research. 357.

https://digitalcommons.unl.edu/usgsstaffpub/357

This Article is brought to you for free and open access by the US Geological Survey at DigitalCommons@University of Nebraska - Lincoln. It has been accepted for inclusion in USGS Staff -- Published Research by an authorized administrator of DigitalCommons@University of Nebraska - Lincoln. 


\title{
Hydrologic properties of coal beds in the Powder River Basin, Montana I. Geophysical log analysis
}

\author{
Roger H. Morin* \\ United States Geological Survey, Denver, CO 80225, USA
}

Received 15 December 2003; revised 15 October 2004; accepted 5 November 2004

\begin{abstract}
As part of a multidisciplinary investigation designed to assess the implications of coal-bed methane development on water resources for the Powder River Basin of southeastern Montana, six wells were drilled through Paleocene-age coal beds along a 31km east-west transect within the Tongue River drainage basin. Analysis of geophysical logs obtained in these wells provides insight into the hydrostratigraphic characteristics of the coal and interbedded siliciclastic rocks and their possible interaction with the local stress field. Natural gamma and electrical resistivity logs were effective in distinguishing individual coal beds. Full-waveform sonic logs were used to determine elastic properties of the coal and an attendant estimate of aquifer storage is in reasonable agreement with that computed from a pumping test. Inspection of magnetically oriented images of the borehole walls generated from both acoustic and optical televiewers and comparison with coal cores infer a face cleat orientation of approximately $\mathrm{N} 33^{\circ} \mathrm{E}$, in close agreement with regional lineament patterns and the northeast trend of the nearby Tongue River. The local tectonic stress field in this physiographic province as inferred from a nearby 1984 earthquake denotes an oblique strike-slip faulting regime with dominant east-west compression and north-south extension. These stress directions are coincident with those of the primary fracture sets identified from the televiewer logs and also with the principle axes of the drawdown ellipse produced from a complementary aquifer test, but oblique to apparent cleat orientation. Consequently, examination of these geophysical logs within the context of local hydrologic characteristics indicates that transverse transmissivity anisotropy in these coals is predominantly controlled by bedding configuration and perhaps a mechanical response to the contemporary stress field rather than solely by cleat structure.
\end{abstract}

Published by Elsevier B.V.

Keywords: Coal bed; Fractures; Geophysical logs; Transmissivity; Crustal stress

\section{Introduction}

The production of coal-bed methane (CBM) has increased dramatically over the past decade as

\footnotetext{
* Corresponding author. Tel.: +1 303236 5915; fax: + 1303236 5968.

E-mail address: rhmorin@usgs.gov
}

technological advances have made exploitation more feasible. Specifically, development of CBM wells in the Powder River Basin of Wyoming and Montana (Fig. 1) has expanded from less than 100 wells in 1993 to over 10,000 producing wells by early 2003 (Wyoming Oil and Gas Conservation Commission, 2003) as the full production potential of subbituminous coal is being realized (Pratt et al., 1999). Water is an

0022-1694/\$ - see front matter Published by Elsevier B.V. doi:10.1016/j.jhydrol.2004.11.006 


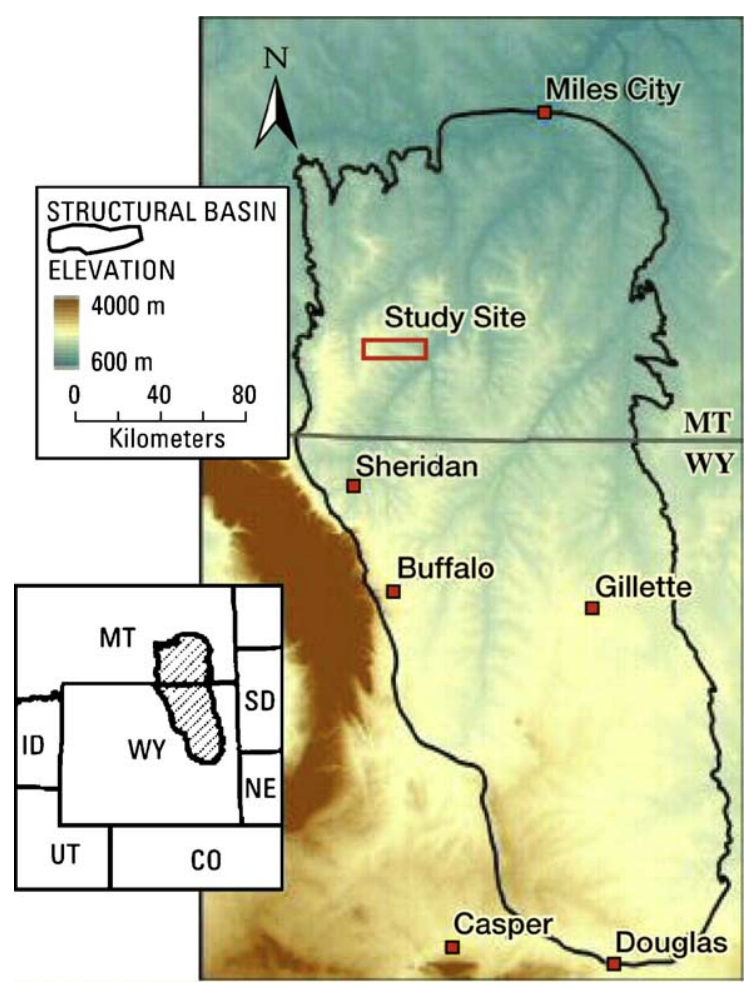

Fig. 1. Map outlining the Powder River Basin and the location of the study site in southeastern Montana.

important by-product of gas extraction as the mixture of water and gas produced in each well is pumped to the surface and separated. This produced water is then discharged into drainages, stored in infiltration ponds, or re-injected into deep aquifers. Records from early 2003 show that roughly 67 million gallons of water per day were being pumped from CBM wells in the Powder River Basin of Wyoming (Wyoming Oil and Gas Conservation Commission, 2003).

It is within this framework that a small-scale, multidisciplinary investigation was undertaken to assess the potential for coal-bed methane development and evaluate its possible impact on water resources in the Powder River Basin of southeastern Montana. One of the unique hydrogeologic characteristics of CBM production is that coal is the source rock as well as the reservoir rock. In addition, coals contain a regularly spaced, naturally occurring system of orthogonal fractures called face cleats and butt cleats. Face cleats are planar, smooth-sided fractures that typically comprise the most extensive fracture set, whereas butt cleats are less prominent and tend to be truncated against face cleats at angles from 80 to $90^{\circ}$ (Laubach and Tremain, 1991). Cleat spacing is influenced by several factors, such as bed thickness and ash content, and a hierarchy of cleat characteristics has been proposed by Laubach et al. (1998). Because face cleats are more continuous than butt cleats, coals often display a marked increase in permeability along the face-cleat direction (e.g. Tyler et al., 1993). In addition, face cleats originate as opening-mode fractures that form parallel to the maximum principal stress. Consequently, their orientation is recognized to be a reliable indicator of ancient stress conditions at the time of coalification (e.g. Engelder and Geiser, 1980; Kulander and Dean, 1993).

In this study, six wells ranging in depth from 108 to $207 \mathrm{~m}$ were drilled through a sequence of coal beds. Coal cores and siliciclastic rock cores were recovered for laboratory measurements of various physical properties and an aquifer test was performed by pumping one well while monitoring three nearby observation wells to determine the hydraulic properties of an isolated coal bed (Weeks, 2004). In addition, comprehensive sets of geophysical logs were obtained to locate coal beds, identify and orient structural features such as cleats and bedding planes, quantify various elastic properties of the formation, and estimate aquifer specific storage.

This paper focuses on the analysis and interpretation of these geophysical logs in order to characterize the stratigraphy of the coal beds and interbedded siliciclastic rocks, to investigate possible correlations between structural patterns and the local stress field, and to examine the implications of these results in terms of the groundwater flow system. General hydrologic properties of the coal are based on the analysis of an aquifer test reported in a companion paper by Weeks (2004).

\section{Hydrogeologic and tectonic settings}

The Powder River Basin trends north-northwest, with northeast aspects in its northern part that conform with the drainage basins of the Tongue and Powder Rivers whose headwaters emanate from the Bighorn Mountains (Fig. 1). The basin structure and extent are primarily delineated by bounding, thrust-faulted 
uplifts such as the Casper arch (southwest), the Black Hills (east), the Hartville uplift (southeast), the Miles City arch (north), and the Bighorn Mountains (west) (e.g. Tyler et al., 1993).

Rocks at the study site are included in the Tongue River Member of the Paleocene Fort Union Formation (Fig. 2). Coals and carbonaceous shales are ubiquitous within this Member and are interbedded with sandstones, siltstones, and mudstones; it is generally recognized that these coal beds serve as the principal aquifers in the region (Davis, 1984). More detailed information regarding the geologic and depositional setting of coal in the basin, as well as a brief history of coal mining in this area, are presented by Flores and Bader (1999).

Numerous investigators have attempted to deduce the tectonic implications of lineament patterns observed at a variety of sites in the Powder River Basin (e.g. Earl, 1976; Saunders and Hicks, 1976; Anna, 1986). Maughan and Perry (1986), in their examination of the Rocky Mountains and adjacent

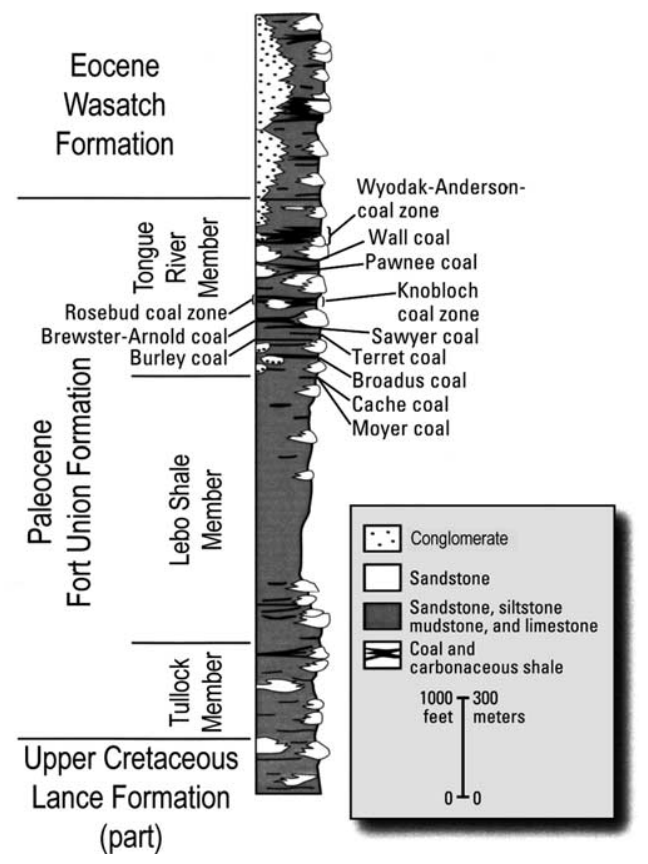

Fig. 2. Stratigraphic column illustrating subdivisions of rocks in the Powder River Basin, Wyoming and Montana. Major coalbeds are identified in the Fort Union and the Wasatch Formations (adapted from Flores and Bader, 1999). Coal cores and geophysical logs were obtained from the Tongue River Member. plains that encompass this study site, identified two orthogonal systems of lineaments, one set trending northeast and the other northwest. These authors offer this information as a possible advancement in understanding the distribution of ancient crustal fracture systems. They, as well as Prucha et al. (1965), hypothesize that these features probably resulted from reactivation of ancient faults or major fracture systems in the underlying crystalline basement rocks.

Thomas (1976) presents a comprehensive examination of lineament-block tectonics and depicts a prominent northeast-trending lineament pattern in the Powder River Basin. The Tongue River and Powder River shear zones are major, subparallel lineaments in this region formed by simple-shear block coupling that has emerged as prominent river channels (Schumm et al., 2000). With the Bighorn Mountains to the west and the Cedar Creek and Black Hills folds to the east, they form a distinctive block pattern in the Powder River Basin (Maughan and Perry, 1986).

\section{Geophysical logs}

Six wells were drilled along a 31-km east-west transect within the Tongue River drainage basin (Fig. 1); they ranged in depth from $108 \mathrm{~m}$ (Well 3) to $207 \mathrm{~m}$ (Well 1). The drilling strategy implemented in this investigation was to drill to the estimated depth of a particular coal bed of interest with a rotary bit, confirm the top of coal by examining cuttings, retrieve the drill pipe and change to a coring bit, and finally recover intact coal cores through the entire thickness of the bed. Once the coal had been satisfactorily sampled, geophysical logging operations were begun. These borehole measurements consisted of caliper, natural gamma activity, long and short normal electrical resistivity, temperature, fluid conductivity, acoustic televiewer, optical televiewer, wellbore deviation, and full-waveform sonic.

\subsection{Lithologic logs}

The gamma and electrical resistivity logs in combination proved to be particularly effective in locating individual coal beds. Shallow and deep (short and long) normal resistivity logs were recorded to compare rock 


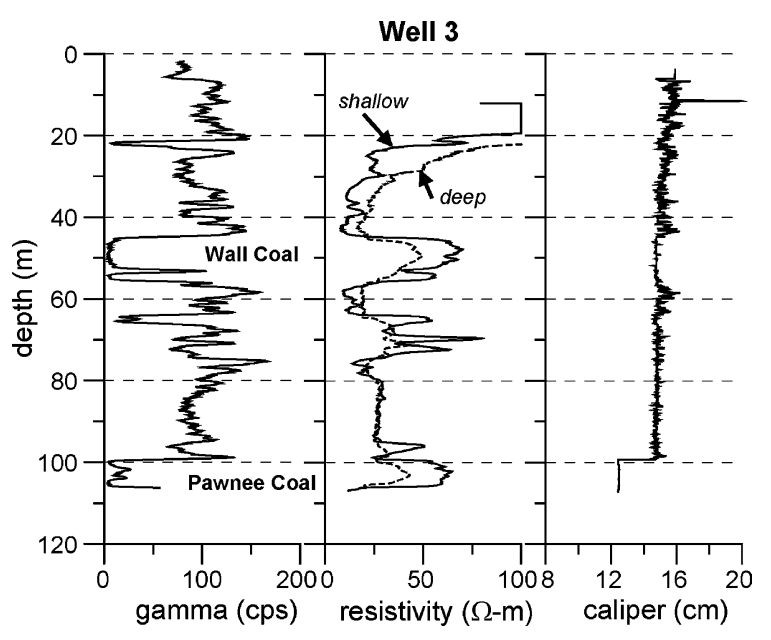

Fig. 3. Geophysical log composite of natural gamma, deep and shallow resistivity (long and short normal), and caliper obtained in Well 3.

properties near to and further away from the borehole. The log composite from Well 3 is typical of logs obtained from all six wells (Fig. 3). Intervals of very low gamma activity, in counts per second (cps), and relatively high resistivities clearly distinguish the coals from the sandstones, siltstones, and shales. A crossplot of these two logs emphasizes the coal cluster (Fig. 4). The accompanying caliper log (Fig. 3), which provides a measure of borehole diameter, displays a sharp diameter reduction at a depth of $99 \mathrm{~m}$ corresponding to a change from a rotary bit to a coring bit.

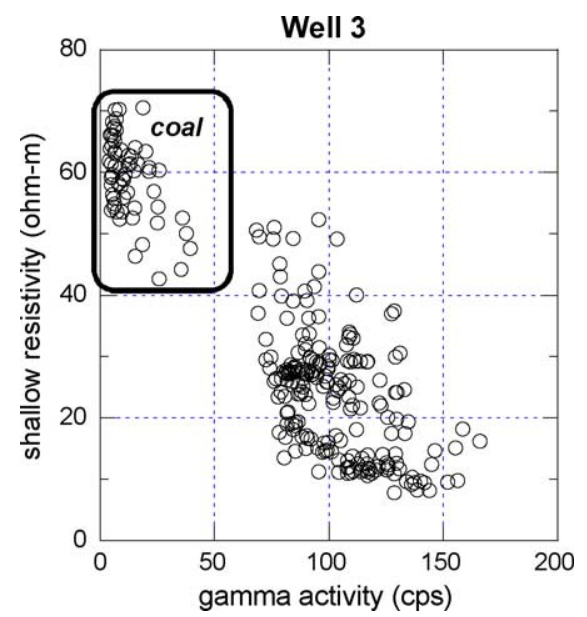

Fig. 4. Crossplot of gamma activity versus shallow resistivity from Well 3 showing data cluster associated with coal.
The electric logs were not corrected for wellbore effects to arrive at estimates of true formation resistivity (Hearst et al., 2000); rather they were examined and compared as individual traces. Of particular interest in the log composite shown in Fig. 3 are the relative magnitudes of the shallow and deep resistivities. In zones where there is separation between these two logs (20-43 m), the deep resistivity is typically greater than the shallow due to small drilling-induced fractures near the borehole that artificially reduce the shallow resistivity but do not affect the deep. In zones where separation is negligible (79-95 m), rock conditions near to and further away from the borehole are similar. This may indicate that the rock is harder and less susceptible to borehole damage (see caliper). Finally, in zones where there is separation between the two logs but where the relative resistivity values of the shallow and deep measurements have reversed (i.e. shallow $>$ deep), this effect is usually attributed to the invasion of drilling mud into the formation and marks the location of a permeable zone. The resistive drilling mud accumulates in an annulus coincident with fluid transfer into the surrounding rock and causes the shallow resistivity to increase without significantly influencing the deep measurement. This condition is clearly demonstrated in Fig. 3 at the two major coal beds $(45-55 \mathrm{~m} ; 99-106 \mathrm{~m})$ and indicates that these coals have the potential to be important aquifers. Thus, the shallow and deep resistivity logs not only help identify the coal beds, but their relative magnitudes and separation also signify an enhanced permeability associated with these units.

Because the natural gamma logs were systematically collected in all six wells across an east-west transect, they may be linked together to provide stratigraphic information laterally across the study site. The gamma logs are plotted as a function of elevation in Fig. 5 and the main coal beds, in descending stratigraphic sequence, are the Canyon, Wall, Pawnee, Knobloch and Flowers-Goodale.

\subsection{Sonic $\log s$}

Because of time constraints in the field and limited tool availability, sonic logs could only be obtained in Well 6. The sonic tool is equipped with a variablefrequency transmitter and two receivers, and has two 


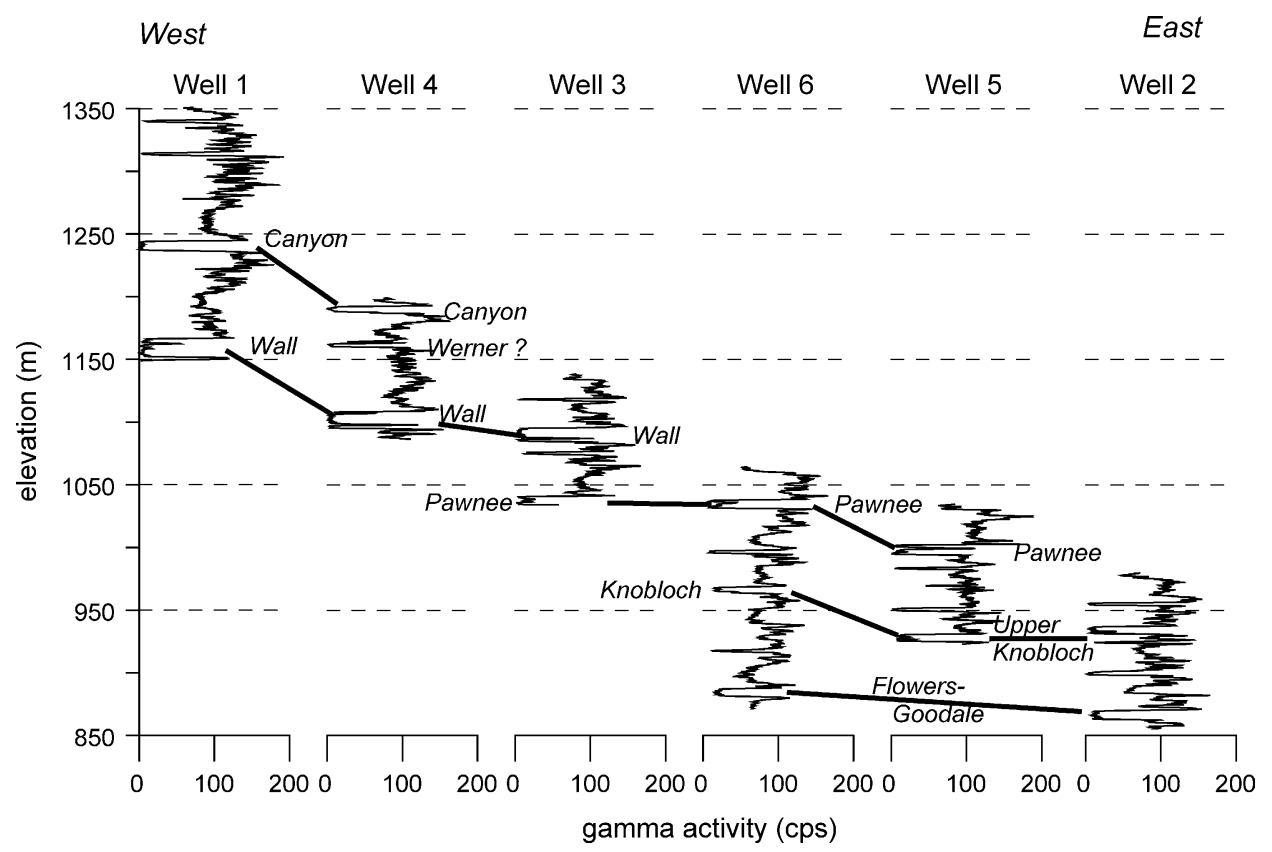

Fig. 5. Coal correlations across the study site constructed from natural gamma logs plotted as a function of elevation. Main coal beds in the Tongue River Member (see Fig. 2) are labeled. Vertical exaggeration is 40:1.

sets of metal centralizers. It was initially run at a frequency of $15 \mathrm{kHz}$ to generate strong acoustic-wave first arrivals and facilitate the determination of compressional wave velocity, $V_{\mathrm{P}}$. Because the coals and siliciclastic rocks encountered at this site are relatively soft, a second sonic log was recorded at a lower transmitter frequency of $3 \mathrm{kHz}$ to preferentially excite slower acoustic energy and arrive at estimates of shear wave velocity, $V_{\mathrm{S}}$, using a semblance algorithm (Paillet and Cheng, 1991). Because the dispersive wave pulse generated under these conditions travels at a velocity slightly slower than the true shear wave for coal, values of $V_{\mathrm{S}}$ are typically underestimated by 10-20\% (Paillet and Cheng, 1991) and these were adjusted accordingly.

A log of compressional velocity recorded in Well 6 is shown in Fig. 6 alongside the corresponding gamma $\log$ and confirms that these sonic data also are effective lithologic indicators; the distinctive log signatures tend to mimic each other and clearly identify the main coal beds penetrated by this well. The Knobloch and Flowers-Goodale coal beds have $V_{\mathrm{P}}$ values of approximately $2.2 \mathrm{~km} / \mathrm{s}$ and the siliciclastic rocks have greater values that approach

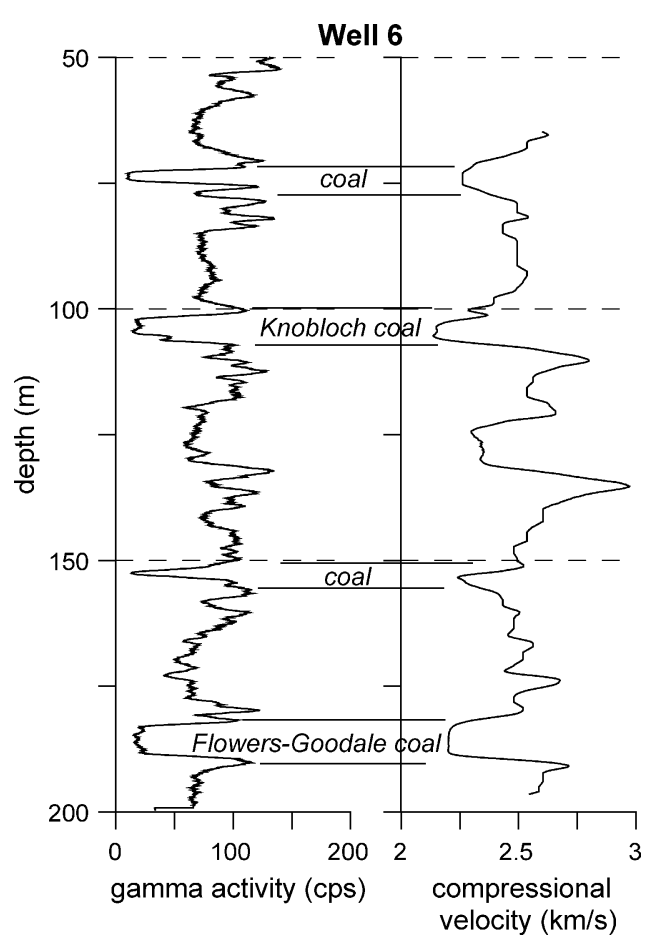

Fig. 6. Compressional velocity $V_{\mathrm{P}}$ and natural gamma logs obtained in Well 6 with major coal beds labeled. 
roughly $2.7 \mathrm{~km} / \mathrm{s}$. Estimates of the slower shear wave velocities are more problematic to recover from the full-waveform logs. Sonic data from some sections of the well contained too much low-frequency noise caused by loose centralizers or ancillary disturbances due to a highly variable borehole diameter to construct a continuous $\log$ of $V_{\mathrm{S}}$ from the full waveforms. However, good-quality data were recovered from a few select intervals that included coals and sandstones and these values are listed in Table 1. No accurate estimate of shear velocity in siltstones could be determined.

Density logs could not be run in these wells due to logistical constraints. Nevertheless, densities were determined from laboratory measurements on several representative core samples, though not from Well 6. Coal densities from various wells ranged from about 1.4 to $1.7 \mathrm{~g} / \mathrm{cm}^{3}$ and siliciclastic rock densities from core samples recovered near Well 1 averaged $2.6 \mathrm{~g} / \mathrm{cm}^{3}$. If it is assumed that these are typical densities for the rocks at Well 6 , these values can be combined with the sonic velocity data to compute various elastic properties of the particular units, including aquifer specific storage $S_{\mathrm{S}}$. First, Poisson's ratio $v$ can be determined (White, 1983) from the relation,

$v=\frac{V_{\mathrm{P}}^{2}-2 V_{\mathrm{S}}^{2}}{2\left(V_{\mathrm{P}}^{2}-V_{\mathrm{S}}^{2}\right)}$

This expression is valid for elastic, isotropic materials and, as a first-order approximation, it is assumed that the siliciclastic rocks comply with this criterion. Although coal is a highly anisotropic material at the centimeter-to-meter scale with its well-defined cleat structure (e.g. Saulsberry et al., 1996), it can be considered isotropic at the grain scale. Coals of the Powder River Basin typically have homogeneous

Table 1

Average sonic and elastic properties

\begin{tabular}{llllll}
\hline & $\begin{array}{l}V_{\mathrm{P}} \\
(\mathrm{km} / \mathrm{s})\end{array}$ & $\begin{array}{l}V_{\mathrm{S}} \\
(\mathrm{km} / \mathrm{s})\end{array}$ & $\begin{array}{l}\rho_{\mathrm{r}}(\mathrm{g} / \\
\left.\mathrm{cm}^{3}\right)\end{array}$ & $v$ & $S_{\mathrm{S}}\left(\mathrm{m}^{-1}\right)$ \\
\hline $\begin{array}{l}\text { Average } \\
\text { coal }\end{array}$ & 2.20 & 1.18 & 1.55 & 0.30 & $2.2 \times 10^{-6}$ \\
$\begin{array}{l}\text { Average } \\
\text { sandstone }\end{array}$ & 2.70 & 1.50 & 2.62 & 0.27 & $8.7 \times 10^{-7}$ \\
$\begin{array}{l}\text { Average } \\
\text { siltstone }\end{array}$ & 2.45 & - & 2.56 & - & - \\
\hline
\end{tabular}

microscopic constituents, called macerals, that primarily consist of vitrinite. Van Krevelen (1981) reports that Poisson's ratio for vitrinite is independent of orientation (i.e. isotropic) when carbon content does not exceed $90 \%$; beyond this threshold, values of $v$ diverge significantly with respect to axis orientation. Van Krevelen (1981) also shows that this same dependence on carbon content holds for Young's and shear moduli as well as for compressibility. Because carbon contents at this site are significantly below $90 \%$, coals are therefore assumed to be isotropic materials at the grain scale with respect to their elastic properties.

Bulk modulus $K$ of the formation can be estimated from sonic properties (White, 1983; Berryman, 2000) if rock densities, $\rho_{\mathrm{r}}$, are known.

$K=\rho_{\mathrm{r}}\left[\frac{3 V_{\mathrm{P}}^{2}-4 V_{\mathrm{S}}^{2}}{3}\right]$

The bulk compressibility of the formation $M$ is the inverse of the modulus.

$M=\frac{1}{K}$

Aquifer specific storage $S_{\mathrm{S}}$, in units of $\left(\mathrm{L}^{-1}\right)$, is defined as (e.g. Freeze and Cherry, 1979)

$S_{\mathrm{S}}=\rho_{\mathrm{f}} g[\alpha+\eta \beta]=\rho_{\mathrm{f}} g M$

where $\rho_{\mathrm{f}}$, fluid density; $g$, gravitational constant; $\alpha$, matrix compressibility; $\eta$, porosity; and $\beta$, fluid compressibility. The bracketed term in Eq. (4) defines the bulk compressibility of the formation, or $M$ in Eq. (3). Consequently, estimates of specific storage can be computed from log-derived sonic velocities where the densities of the rock and saturating fluid are known. Representative values of $S_{\mathrm{S}}$ for coal and sandstone from Well 6 are listed in Table 1. The magnitude of $S_{\mathrm{S}}$ for these coals is about $2 \times 10^{-6} \mathrm{~m}^{-1}$ and is in reasonable agreement with that determined for the Flowers-Goodale coal at Well 2 and reported by Weeks (2004) as being roughly $5 \times 10^{-6} \mathrm{~m}^{-1}$. This latter value is based upon the early-time response of an aquifer test and represents the component of specific storage corresponding to a fractured medium.

\subsection{Borehole image logs}

Magnetically oriented images of the borehole wall were obtained by means of two types of televiewers: 
the acoustic televiewer and the optical televiewer. The acoustic televiewer is equipped with a $500-\mathrm{kHz}$ transducer that rotates at $12 \mathrm{rev} / \mathrm{s}$. The tool is raised in the well at a logging speed of $2 \mathrm{~m} / \mathrm{min}$ and acoustic pulses emitted from and reflected back to the transducer are processed in terms of amplitude and transit time to produce cylindrical projections of the borehole wall. Non-horizontal planes intersecting the borehole appear as sinusoids in the planar images; the sinusoid's low point indicates dip direction and its amplitude is proportional to dip. In this way, strike and dip of fracture planes can be determined through careful inspection of these image logs. More details regarding the principles of operation of the acoustic televiewer may be found in Zemanek et al. (1970).

Generating images in coal with this tool was often problematic because of the poor acoustic impedance contrast between the borehole fluid (water) and the low-density coal. The acoustic impedance of a medium is defined as the product of its density and compressional wave velocity. For normal incidence, the reflection coefficient, $R$, of an acoustic pulse traveling through medium 1 (water) and reflecting off the interface with medium 2 (rock formation) is represented by the expression,

$R=\frac{\rho_{2} V_{\mathrm{P} 2}-\rho_{1} V_{\mathrm{P} 1}}{\rho_{2} V_{\mathrm{P} 2}+\rho_{1} V_{\mathrm{P} 1}}$

Because of the relatively small density contrast between water and coal, the reflection coefficient often was not large enough to provide an adequate return pulse from which to generate an acoustic image. With a typical density of roughly $1.55 \mathrm{~g} / \mathrm{cm}^{3}$ and a compressional velocity of about $2.20 \mathrm{~km} / \mathrm{s}$ for coal, corresponding values of $R$ are roughly on the order of 0.40 .

This magnitude for the acoustic reflection coefficient is marginal for producing an adequate pulse reflection and, consequently, successful data acquisition in coal was inconsistent. Small fluctuations in this $R$ value occasionally caused acoustic images to emerge with enough clarity to identify specific features in the coal or to disappear altogether. An illustration of this latter case is shown in Fig. 7(a), where a coal bed in Well 5 at a depth of 52.3 to $54.0 \mathrm{~m}$ is located between sandstones and siltstones. The acoustic televiewer image of the coal, here depicted as

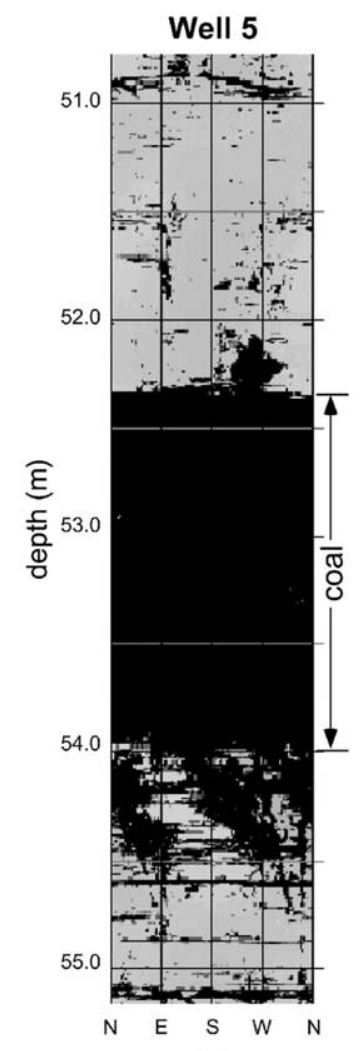

(a)

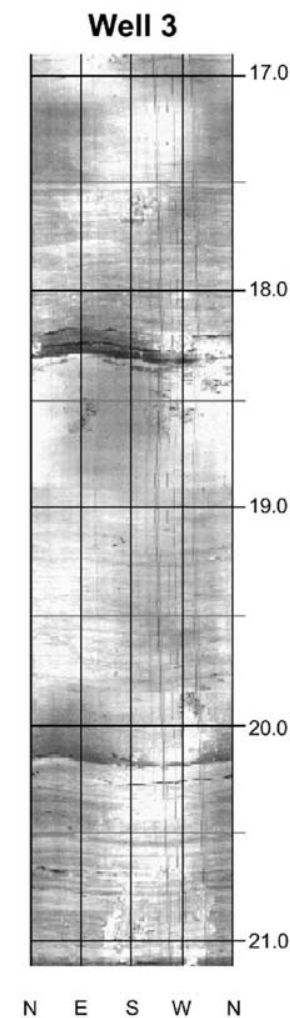

(b)
Fig. 7. (a) Acoustic televiewer image of coalbed between siliciclastic rocks in Well 5. (b) Optical televiewer image of siliciclastic rocks below water table in Well 3.

an 'unwrapped', magnetically oriented view of a cylinder, is essentially nonexistent (no return signal), whereas the reflected data from the siliciclastic rocks are strong enough to discern some lithologic detail.

The optical televiewer also provides a digital, magnetically oriented view of the borehole wall through the manipulation of an optical camera and light source. Although contrasts in acoustic impedance pose no inherent difficulties in its proper operation, it does require a transparent medium in the borehole (i.e. air or clean water). In many cases, time limitations did not allow the wells to be properly flushed and developed before logging, and the borehole water was murky. Thus, data generated from the optical televiewer are often of poor quality below the water table. In Well 3, where the borehole fluid was relatively clear, a planar, magnetically oriented image 
(Fig. 7(b)) reveals lithologic contacts and bedding dipping gently to the southwest (low points of sinusoids).

The acoustic televiewer functioned consistently well in the siliciclastic rocks where, unlike coal, density contrasts between the formation and borehole fluid were adequate to produce a detectable reflection. Nevertheless, this logging tool was modestly successful in coals on occasion if the reflection coefficient improved slightly due to subtle increases in density. This was the case in Well 1, where a dominant subvertical fracture observed in the core (Fig. 8(a)) is also recognized in the televiewer image (Fig. 8(b)). Close inspection of the core showed this major fracture to be along a face cleat and the digital televiewer data, corrected for local magnetic declination, identify this feature as dipping very steeply to the southeast and striking at $\mathrm{N} 33^{\circ} \mathrm{E}$ (dip direction minus $90^{\circ}$ ). Face cleats such as this one that similarly correspond to extensive fractures in core were identified in three other wells in this manner (Wells 3 , 5, and 6). All have a common orientation, indicating that cleat structure is fairly uniform across the $31-\mathrm{km}$ transect encompassed by this study site.

Assuming that cleat orientation is a reliable recorder of stress conditions at the time of coalification (e.g. Engelder and Geiser, 1980), the face-cleat orientation of $\mathrm{N} 33^{\circ} \mathrm{E}$ is consistent with the state of tectonic forces implied from lineament analysis. This orientation is subparallel to the trends of both the Tongue River and the Powder River (Fig. 1), and is aligned with the major lineament patterns (Maughan and Perry, 1986), faults and folds (Robinson and Barnum, 1986), and shear zones (Thomas, 1976) in the region.

A prominent fracture along a cleat was the only discernable feature that could occasionally be recognized from the televiewer logs recorded in coal, and eight of these were identified in four wells (Wells 1, 3, 5 , and 6). The paucity of these features is presumably more a function of limitations in televiewer data acquisition than it is of true coal characteristics. However, numerous other planar features were identified in the interbedded siliciclastic rocks (see Fig. 7). Inspection of both types of televiewer logs (acoustic and optic) from all wells revealed 144 fractures and/or bedding planes. Their orientations, including those of the cleats, are depicted in the rosette

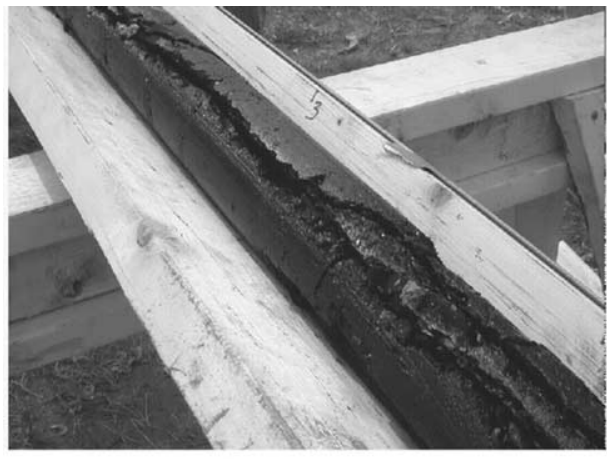

(a)

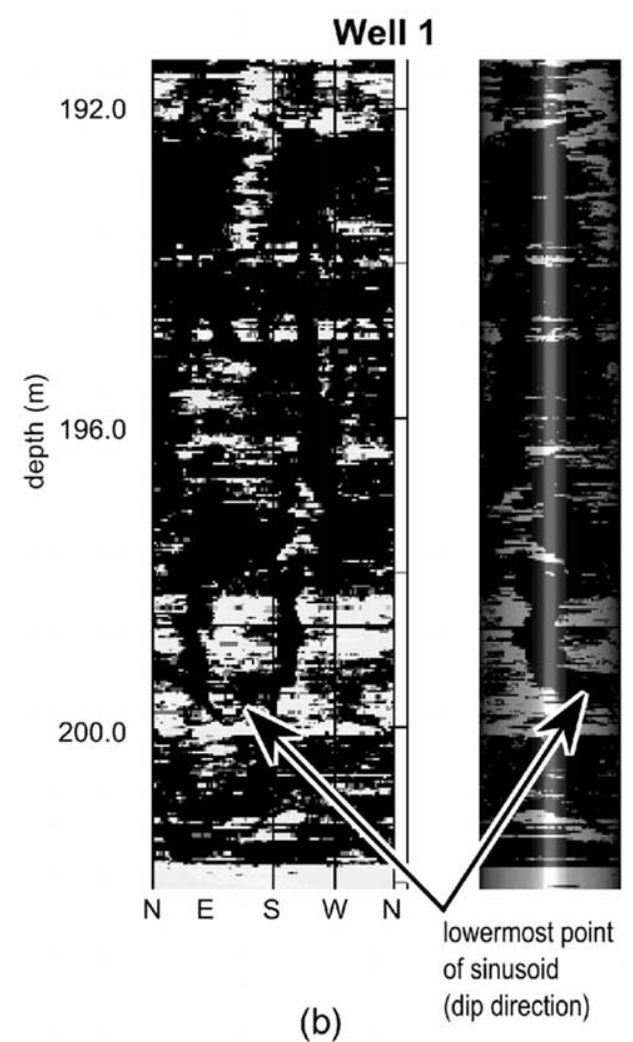

Fig. 8. (a) Photograph of coal core showing subvertical fracture corresponding to major face cleat. (b) Acoustic televiewer log showing same prominent feature (high amplitude sinusoid). Panels represent (left) magnetically oriented planar view and (right) cylindrical projection.

and equal-area, lower-hemisphere stereographic plots shown in Fig. 9 ( $N$, total number of planes, 152). The rosette illustrates the strike of the planes; the stereogram includes dip information. The large 

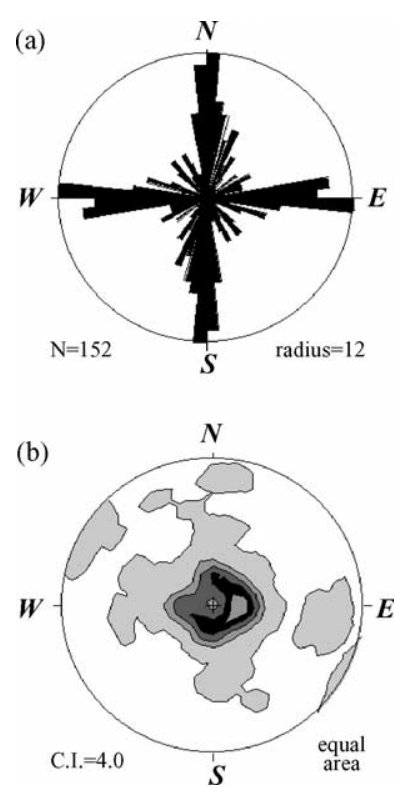

Fig. 9. (a) Rosette based on strike and (b) lower hemisphere, equal area stereographic diagram depicting orientations of planar features as determined from inspection of televiewer data across all lithologies from all six wells. $N$, number of planes and C.I., contour interval.

majority of these planes are sub-horizontal, dipping less than $20^{\circ}$, and may be divided into two general populations. One set strikes east-west and the other north-south.

\section{Crustal stresses and hydrologic properties}

\subsection{Stress and false breakouts}

Although ancient stress directions might be implied from cleat orientations in coal beds, the contemporary stress field at this study site is somewhat complex because it is located near the transition between the Great Plains and the Middle Rocky Mountains physiographic provinces (Zoback and Zoback, 1989) and includes the superimposed effects of tectonics and topography. One well-established method of inferring stress conditions is by identifying stress-induced features in a borehole from televiewer images and invoking stress models that predict their characteristic appearance. Breakouts are such features. They consist of stress-induced zones of shear failure at the borehole wall that are aligned parallel to the direction of the minimum horizontal principal stress, $S_{\mathrm{hmin}}$, and orthogonal to the direction of the maximum horizontal principal stress, $S_{\text {HMAX }}$ (e.g. Bell and Gough, 1979; Zoback et al., 1985; Morin et al., 1990). Consequently, the appearance of breakouts in a well permits the orientation of contemporary principal stresses at a site to be deduced. An example of 'classic' breakout images as recorded with an acoustic televiewer is presented in Fig. 10(a) (Savage and Morin, 2002); notice the two dark vertical bands separated by exactly $180^{\circ}$ (east-west) that represent zones of rock failure aligned with $S_{\mathrm{hmin}}$.

A section of the acoustic televiewer log recorded in Well 3 is displayed in Fig. 10(b) (planar view) and (c) (cylindrical view), and apparently depicts a series of short, intermittent breakouts in coal. Damaged zones are separated azimuthally by about $180^{\circ}$ and appear over a roughly 4-m depth interval. However, also evident, particularly in the cylindrical projection, are very steep fractures or lobes that seemingly emanate from these apparent breakouts and have a common strike. The highly anisotropic nature of this coal in terms of strength at the centimeter-to-meter scale implies that the steep fractures might represent parallel face cleats and that the apparent breakouts are simply zones of rock failure aligned along preferential planes of weakness (Jaeger and Cook, 1969; Amadei and Stephansson, 1997). Consequently, the televiewer images presented in Fig. 10(b) and (c) are not directly analogous to the breakouts shown in Fig. 10(a). Although they are inherently stressinduced features, they do not reveal any information regarding stress orientation; rather, they depict planes of weakness in an anisotropic (in terms of strength, not elastic properties) material (Daemen, 1983). Despite this qualification, they do nevertheless represent additional observations of face cleats, again striking $\mathrm{N} 33^{\circ} \mathrm{E}$ and consistent with those shown in Fig. 8.

Information regarding contemporary tectonic stress also may be gleaned from another source, that of nearby earthquakes and their focal mechanisms. These data can provide evidence of the particular set of crustal stresses to which the rocks are subjected (e.g. Golombek, 1985). A review of earthquake activity near this study site shows that a magnitude 


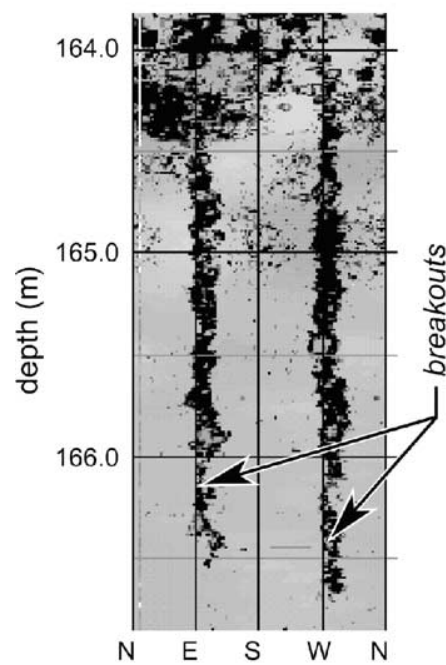

(a)

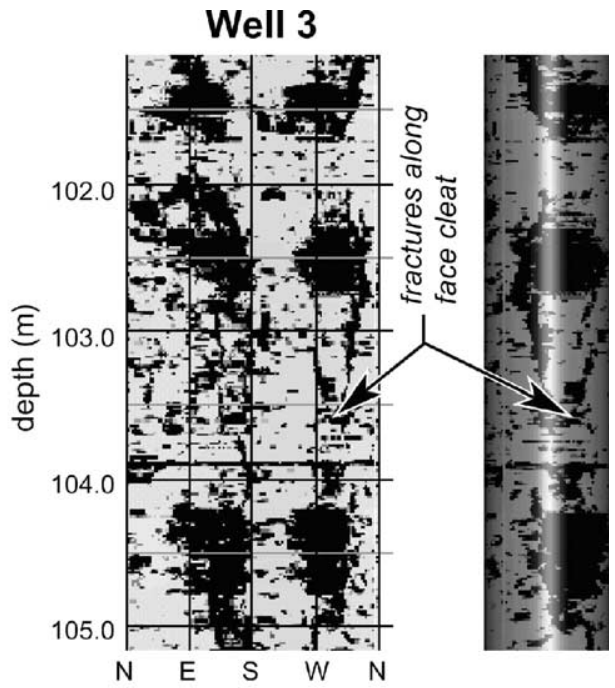

(b)

(c)

Fig. 10. (a) Televiewer log showing the appearance of typical breakouts in magnetically oriented planar view of volcanic rocks in Texas (after Savage and Morin, 2002). (b) Televiewer log from Well 3 showing intermittent zones of damaged wellbore (false breakouts) in coal along with subvertical fractures (cleats), also in planar view. (c) Cylindrical projection of adjacent panel b.

4.9 seismic event occurred in 1984 about $110 \mathrm{~km}$ to the southeast (Fig. 11). A source-solution analysis indicates that this earthquake originated from a depth of about $20 \mathrm{~km}$ and defines an oblique strike-slip faulting environment with dominant east-west compression and north-south extension (Dziewonski et al., 1985), as represented by the stress cube and the 'beachball' diagram in Fig. 11. Thus, corroborating information derived from cleat characteristics in the coal beds and from focal-plane solutions of a recent earthquake implies that the orientation of crustal stresses in this region has changed over time, from an $S_{\mathrm{HMAX}}$ direction of about $\mathrm{N} 33^{\circ} \mathrm{E}$ during Late Paleocene deposition and coalification to a presentday east-west direction. Gries (1983) refers to this transition when describing Eocene east-west trending thrusts and folds in the region that truncate earlier Laramide north-south trending thrusts and folds.

In the companion paper, Weeks (2004) reports on the results of a multi-well aquifer test conducted in Well 2 across an isolated, lowermost coal interval (Flowers-Goodale coal; see Fig. 5). A central well (Well 2) was pumped at a rate of $30 \mathrm{~L} / \mathrm{min}$ for $9 \mathrm{~h}$ and the hydrologic responses in three nearby observation wells were monitored. Analysis of these data indicates

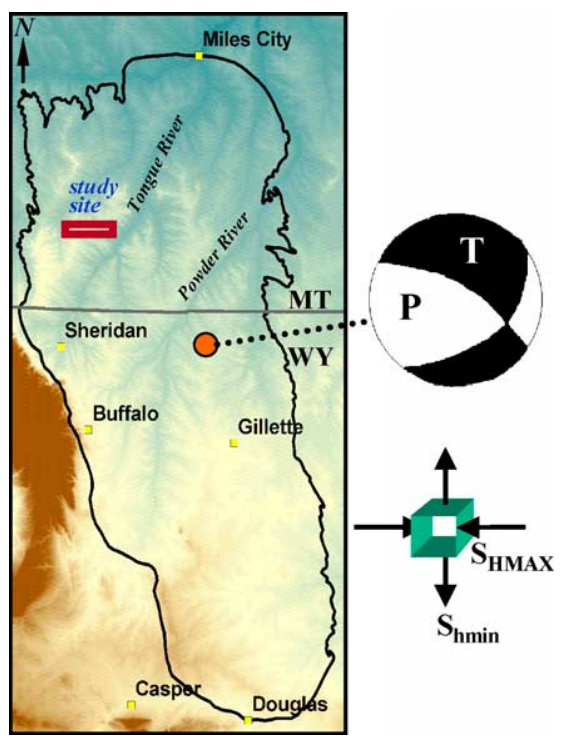

Fig. 11. Focal plane solutions of 1984 earthquake located $110 \mathrm{~km}$ southeast of study area. Beachball diagram describes an oblique strike-slip faulting environment, with dominant east-west compression and north-south extension as illustrated by the stress cube. $P$, compression; $T$, tension. See Meissner (1986) for additional explanation of diagram construction. 


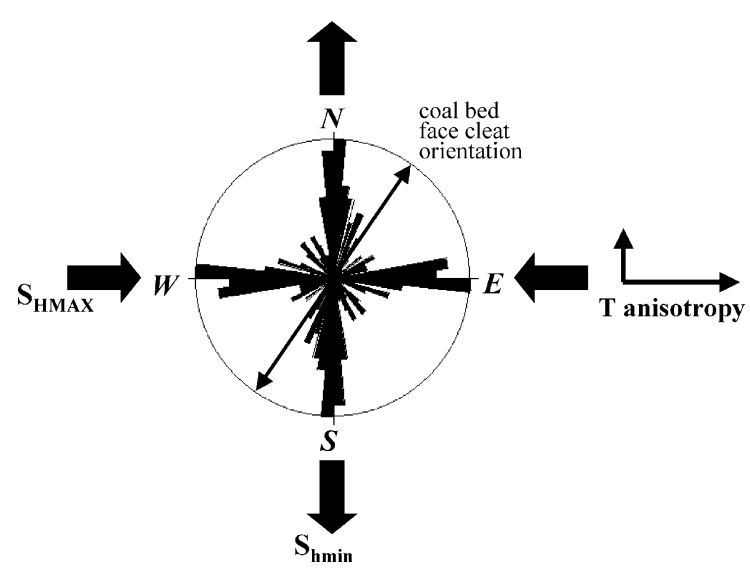

Fig. 12. Diagram depicting interplay among physical characteristics at this study site. Orientations of fractures (strike rosette), coal-bed face cleats, contemporary stresses, and relative coal-bed transmissivity $T$ are presented.

that the coal bed has a transverse transmissivity anisotropy ratio of 2.2:1. Moreover, the corresponding drawdown ellipse identifies the major axis of this anisotropy to be oriented east-west. Thus, the direction of primary transmissivity is aligned with both the direction of dominant contemporary compressional stress and with one of the major fracture sets, but oblique to the interpreted cleat orientation. These observations are summarized in Fig. 12.

\subsection{Generalized structure and simple model}

To properly conduct the multi-well aquifer test planned at Well 2, exact distances between measurement points at depths of interest were required. Consequently, deviation logs were obtained in the four wellbores associated with this test (one pumping well and three observation wells) to record their threedimensional positions in space. The resulting polar diagrams presented in Fig. 13 show three of the four wells to be gradually drifting to the south-southeast with increasing depth. It should be noted that the slant angle in these wells never exceeded $2^{\circ}$ and, consequently, the dips of fracture planes estimated from examination of televiewer logs were not corrected for borehole deviation as this amount of inclination is within the resolution of the measurement technique.

These relatively uniform wellbore trajectories are likely a consequence of the combined effects of two orthogonal structural components within these rocks that strike east-west and north-south. Morin (2000) recognized a correlation between wellbore deviation and structure in fractured sedimentary rocks, where the inclination of the borehole is oriented roughly perpendicular to the general strike of bedding planes. This correspondence between inclination and structure often has been observed in cases of rotary drilling through rocks, where the drillbit follows a path of least resistance as determined by stratigraphy and is continually prodded updip. McDonald et al. (1997) also have reported this type of behavior in crystalline rocks having distinctive foliation bands.

The deviation trends observed in the four aquifertest wells tend to bisect the fracture orientation data (Fig. 9). However, with increasing depth, three of the four wells systematically rotate clockwise to the south, inferring that the east-west striking fracture set begins to dominate structurally. This direction also is consistent with the orientations of $S_{\text {HMAX }}$ and the primary transmissivity axis (Fig. 12). This correlation implies a possible link among the crustal stresses imposed upon the rocks, the distribution of fractures interspersed within the rocks, and the preferential directions of groundwater flow through the rocks.

A suggested coupling of tectonic and hydrologic processes can be investigated further through the application of simple rock-mechanics principles. The mechanical response of a rock mass to tectonic loading can produce fractures (e.g. Pollard and Aydin, 1988) and particular sets of stress conditions can significantly alter the hydraulic properties of fractured rocks (e.g. Bruno et al., 1991; Rutqvist and Stephansson, 2003). Various field studies have shown evidence of enhanced permeability associated with fracture planes that are optimally oriented for failure in the contemporary stress field (Bell and Babcock, 1986; Barton et al., 1995). To demonstrate this relation, Hillis (1998) developed a two-dimensional model for closure of fractures with varying alignment under the influence of maximum and minimum horizontal principal stresses, $S_{\text {HMAX }}$ and $S_{\text {hmin }}$. Morin and Savage (2003) extended this work to quantify the closure of rock fractures in response to a three-dimensional stress field and to examine the effects of this closure on the hydraulic properties of a rock mass.

The relation for closure, $d$, of a mated joint or fracture plane as a function of normal stress, $\sigma_{\mathrm{n}}$, 


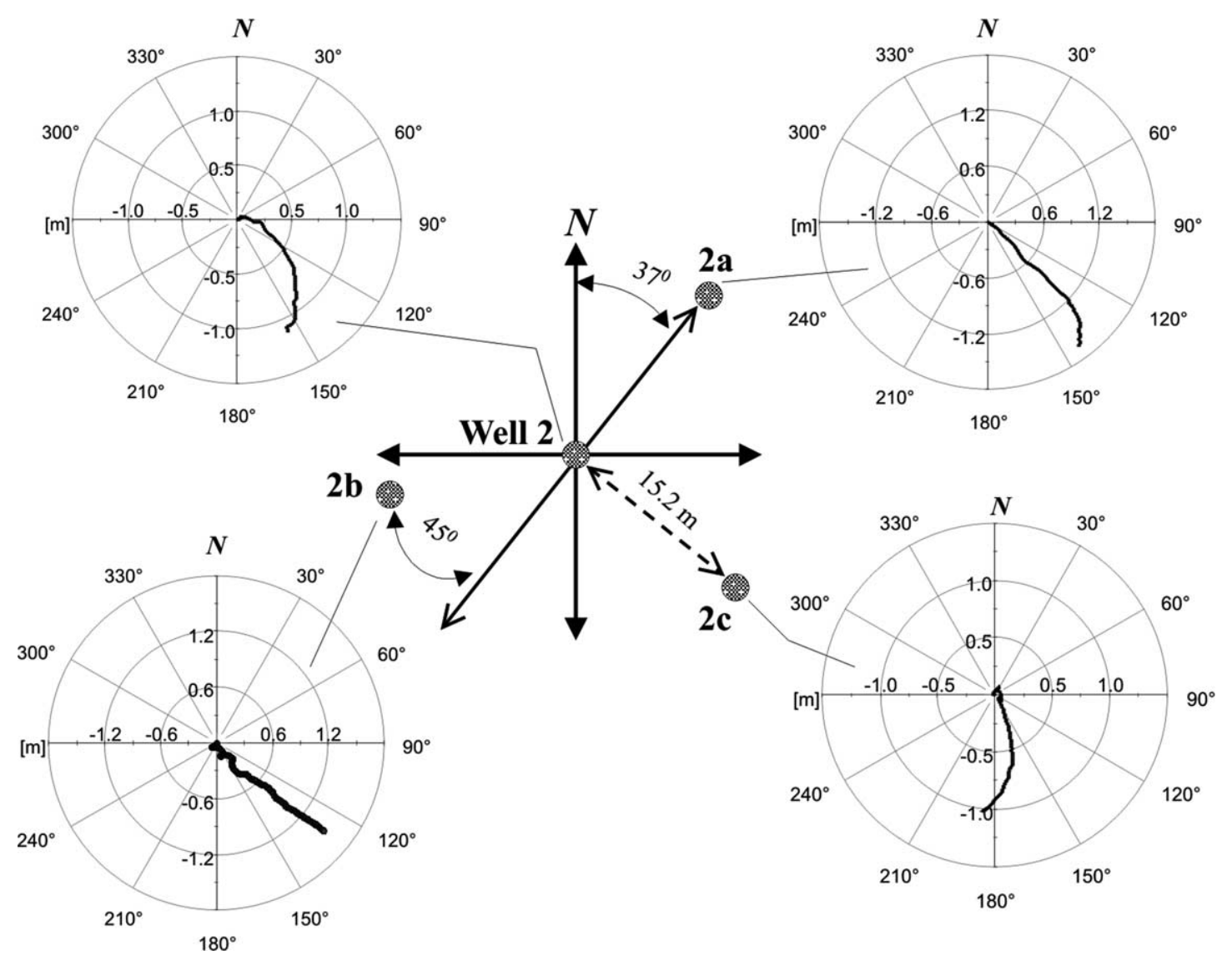

Fig. 13. Wellbore deviation plots for pumped well (Well 2) and three nearby observation wells used in aquifer test (see Weeks, 2004). Polar diagrams follow wellbore trajectories in horizontal plane $(\mathrm{m})$ with respect to depth; target centers represent well locations at surface.

(Hudson and Harrison, 1997) is given by

$d=\frac{d_{\mathrm{m}} \sigma_{\mathrm{n}}}{\sigma_{\mathrm{n}}+W_{\mathrm{i}} d_{\mathrm{m}}}$

where $d_{\mathrm{m}}$ is the maximum joint closure and $W_{\mathrm{i}}$ is defined as the initial joint stiffness. This expression is hyperbolic and, consequently, joint closure asymptotically approaches a maximum value as the normal stress increases.

Conversely, joint aperture is expressed as $\varsigma=\varsigma_{0}-$ $d$, where $\varsigma_{0}$ is the initial joint aperture. Substituting this relation into Eq. (6) yields,

$\varsigma=\varsigma_{0}-\frac{d_{\mathrm{m}} \sigma_{\mathrm{n}}}{\sigma_{\mathrm{n}}+W_{\mathrm{i}} d_{\mathrm{m}}}$

The normalized ratio $\varsigma / \varsigma_{0}$ is equal to 1 in the absence of a normal load and the fracture plane maintains its initial, or original, thickness. Joint aperture, $\varsigma$, asymptotically approaches $\left(\varsigma_{0}-d_{\mathrm{m}}\right)$ for large values of $\sigma_{\mathrm{n}}$ as the plane is squeezed shut. This is conceptually equivalent to the network model developed by Sayers (1990) in which hydraulic conductivity anisotropy in a fractured medium develops in response to applied forces as some fractures are systematically closed while others are preferentially opened.

The normal stress, $\sigma_{\mathrm{n}}$, acting on an arbitrarily oriented plane may be expressed as a component of the three principal stresses through Cauchy's formula (Jaeger and Cook, 1969). Cauchy's formula may then be combined with Eq. (7) to predict the closure of randomly oriented planes subjected to crustal stresses specified by the magnitudes and orientations of $S_{\mathrm{HMAX}}, S_{\mathrm{hmin}}$, and $S_{\mathrm{V}}$, the vertical principal stress. Savage and Swolfs (1987) developed a computer 
program to perform this analysis, whereby estimates of joint closure are computed as a function of orientation with respect to the stress field. Results may then be depicted on equal-area, lower hemisphere stereographic diagrams.

Morin and Savage (2003) used this method to determine the response of fracture planes to generalized deep and shallow stress conditions in a sedimentary basin. Their results are included in Fig. 14 for the shallow case, where the vertical stress equals the least principal stress, and illustrate dimensionless joint aperture in response to maximum and minimum horizontal principal stresses that are oriented eastwest and north-south, respectively. Dark and light shades represent plane orientations having the greatest and least closure, respectively.

Although stress conditions in the analysis of Morin and Savage (2003) are not identical to those encountered in this study, the stereographic diagram (Fig. 14) provides a qualitative representation of the spatial distribution of fracture planes and their relative apertures in response to stress. It also presents a conceptual view of anisotropic flow patterns as evidenced at this site. Results demonstrate that fracture planes striking east-west and aligned with $S_{\text {HMAX }}$ have a greater relative aperture and, thus, are more likely to be permeable than their counterparts with smaller apertures that strike north-south and are

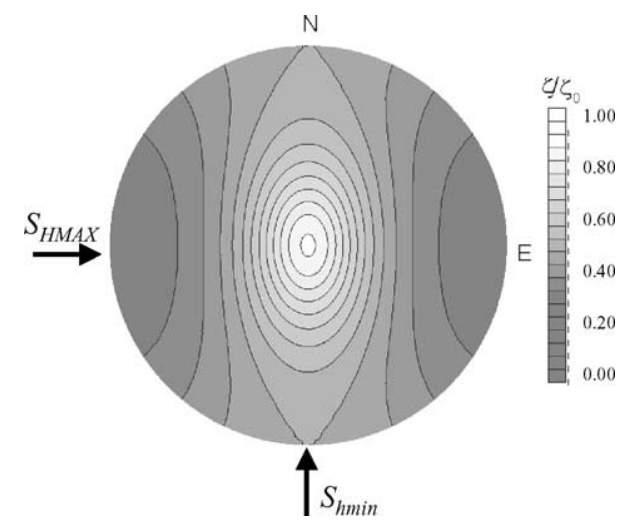

Fig. 14. Stereographic contour plot of dimensionless fracture aperture, $s / \varsigma_{0}$ (after Morin and Savage, 2003). The maximum horizontal stress is oriented east-west, the minimum horizontal stress is oriented north-south, and the vertical stress is the least principal stress so as to represent shallow crustal conditions. Dark and light shades represent plane orientations having the greatest and least closure, respectively. oriented along $S_{\mathrm{hmin}}$. It is noteworthy that the aperture contours in Fig. 14 are orthogonal to the drawdown contours reported by Weeks (2004) and infer an anisotropic hydrologic system consistent with the structural information summarized in Fig. 12.

\section{Summary and discussion}

A suite of geophysical logging tools was deployed in six wells penetrating coals and interbedded siliciclastic rocks to investigate the general hydrologic system at a study site in southeastern Montana. Various $\operatorname{logs}$ met with varying degrees of success. Natural gamma, long and short normal resistivity, and compressional velocity logs were particularly effective in delineating coal beds. Moreover, the relative separation between shallow and deep resistivities and their reversal coincident with coals indicate that coal beds are more permeable than the surrounding rocks and have the potential to be the primary aquifers in the area. Shear velocities were more difficult to extract from the full-waveform sonic logs but, where accurate estimates of $V_{\mathrm{S}}$ could be derived, a value of specific storage for coal was computed that is in reasonable agreement with that determined by Weeks (2004) from an aquifer-test analysis.

Both the acoustic and optical televiewer logs were intermittently effective although both suffered from fundamental data-acquisition limitations. A typically low reflection coefficient across low-density coals often prevented the acoustic televiewer from detecting a return signal. However, this tool consistently functioned well and provided good-quality data in the siliciclastic rocks and occasionally in coals with slightly higher densities. Major face cleats identified in coal cores were recognized in and oriented from the acoustic televiewer images, and fractures and bedding in the sandstones and siltstones also were observed. The optical televiewer identified these latter features as well where the borehole fluid was reasonably clear (air or clean water). To ensure better quality optical televiewer data, more time and effort may be required to adequately flush the wells in order to improve water transparency and to remove drilling mud from the borehole walls.

The face cleat orientation was determined from inspection of the acoustic televiewer logs in coals from four of the six wells and consistently appeared at 
about $\mathrm{N} 33^{\circ} \mathrm{E}$. This direction is subparallel to the trends of the Tongue and Powder Rivers in southeastern Montana and reflects the consequences of an ancient stress field that is manifested in the primary lineament patterns observed in the region (Maughan and Perry, 1986; Robinson and Barnum, 1986). Apparent breakouts in coal also identified from televiewer logs support this same stress orientation. However, the alignment of cleats and breakouts is found to be merely an artifact of the strength anisotropy of coal as it responds to imposed stresses; failure occurs along distinct planes of mechanical weakness that provides no reliable information on stress orientation. The true contemporary stress field as determined from focalplane solutions to a nearby earthquake indicates that the maximum horizontal principal stress, $S_{\text {HMAX, }}$ is now predominantly east-west. Thus, the televiewer images of cleat structure and the earthquake focal mechanisms combine to infer a temporal change in stress conditions from the Late Paleocene to the present day that also is supported by extensive structural studies in the region (Gries, 1983).

The aquifer-test results reported by Weeks (2004) for an isolated coal bed indicate a substantial increase in transverse transmissivity along the east-west direction. This orientation also corresponds to the direction of $S_{\mathrm{HMAX}}$ and the strike of a primary fracture set in the coals and interbedded siliciclastic sediments, but is oblique to cleat orientation (Fig. 12). Consequently, assimilation of this diverse collection of data independently obtained from an aquifer test, from geophysical logs, and from earthquake tensor solutions, indicates that the transverse transmissivity anisotropy measured in coal beds at this site is predominantly controlled by stratigraphic properties and perhaps a mechanical response to contemporary crustal stresses rather than solely by cleat structure.

\section{Acknowledgements}

The author is grateful to L. Anna and S. Sipkin for numerous helpful discussions, and to P. Nelson, S. Roberts, and two anonymous reviewers for their thorough and thoughtful criticisms that significantly improved this manuscript. Logistical help provided by M. Cannon and the professionalism and cooperation of A. Clark and his drilling crew are also greatly appreciated.

\section{References}

Amadei, B., Stephansson, O., 1997. Rock Stress and Its Measurement, V Chapman and Hall, New York p. 490.

Anna, L.O., 1986. Structural influences on Cretaceous sedimentation, Northern Great Plains, in: Peterson, J.A. (Ed.), Paleotectonics and Sedimentation in the Rocky Mountain Region, United States, pp. 173-191. AAPG Memoir 41.

Barton, C.A., Zoback, M.D., Moos, D., 1995. Fluid flow along potential active faults in crystalline rock. Journal of Geology 23 (8), 683-686.

Bell, J.S., Babcock, E.A., 1986. The stress regime of the Western Canadian Basin and implications for hydrocarbon production. Bulletin Canadian Petroleum Geology 34, 364-378.

Bell, J.S., Gough, D.I., 1979. Northeast-southwest compressive stress in Alberta: evidence from oil wells. Earth Planetary Science Letters 45, 475-482.

Berryman, J.G., 2000. Seismic velocity decrement ratios for regions of partial melt in the lower mantle. Geophysical Research Letters 27 (3), 421-424.

Bruno, M.S., Bovberg, C.A., Nakagawa, F.M., 1991. Anisotropic stress influence on the permeability of weakly-cemented sandstones, in: Roegiers, A. (Ed.), Rock Mechanics as a Multi-Disciplinary Science. A.A. Balkema Press, Rotterdam, pp. 351-361.

Daemen, J.J.K., 1983. Slip zones for discontinuities parallel to circular tunnels or shafts. International Journal Rock Mechanics Mining Science \& Geomechanics Abstracts 20 (3), 135-148.

Davis, R.E., 1984. Geochemistry and geohydrology of the West Decker and Big Sky coal-mining areas, southeastern Montana. USGS Water-Resources Investigations Report 83-4225, p. 109.

Dziewonski, A.M., Franzen, J.E., Woodhouse, J.H., 1985. Centroidmoment tensor solutions for July-September, 1984. Physics Earth and Planetary Interiors 38, 203-213.

Earl, J.L., 1976. A study of the tectonics of Wyoming and adjacent areas using photo linear elements mapped from LANDSAT-1 and Skylab imagery, in: Podwysocki, M.H., Earle, J.L. (Eds.), Proceedings of Second International Conference of Basement Tectonics, Newark, Delaware, pp. 165-176.

Engelder, T., Geiser, P., 1980. On the use of regional joint sets as trajectories of paleostress fields during development of the Appalachian Plateau. Journal of Geophysical Research 85, 6319-6341.

Flores, R.M., Bader, L.R., 1999. Fort Union coal in the Powder River Basin, Wyoming and Montana: a Synthesis, Chapter PS in U.S. Geological Survey Professional Paper 1625-A.

Freeze, R.A., Cherry, J.A., 1979. Groundwater. Prentice-Hall, Englewood Cliffs, New Jersey, p. 604.

Golombek, M.P., 1985. Fault type predictions from stress distributions on planetary surfaces: Importance of fault initiation depth. Journal of Geophysical Research 90, 3065-3074.

Gries, R., 1983. North-south compression of Rocky Mountain foreland structures, in: Lowell, J.D. (Ed.), Rocky Mountain Foreland Basins and Uplifts. Rocky Mountain Association of Geologists, pp. 9-32.

Hearst, J.R., Nelson, P.H., Paillet, F.L., 2000. Well Logging for Physical Properties, 2 John Wiley and Sons, New York p. 483. 
Hillis, R.R., 1998. The influence of fracture stiffness and the in situ stress field on the closure of natural fractures. Petroleum Geoscience 4, 57-65.

Hudson, J.A., Harrison, J.P., 1997. Engineering Rock Mechanics; an Introduction to the Principles. Pergamon, London p. 444.

Jaeger, J.C., Cook, N.G.W., 1969. Fundamentals of Rock Mechanics, 1 Methuen, New York p. 513.

Kulander, B.R., Dean, S.L., 1993. Coal-cleat domains and domain boundaries in the Allegheny Plateau of West Virginia. AAPG Bulletin 77, 1374-1388.

Laubach, S.E., Tremain, C.M., 1991. Regional coal fracture patterns and coalbed methane development, in: Roegiers, A. (Ed.), Rock Mechanics as a Multidisciplinary Science. A.A. Balkema Press, Rotterdam, pp. 851-859.

Laubach, S.E., Marrett, R.A., Olson, J.E., Scott, A.R., 1998. Characteristics and origins of coal cleat: a review. International Journal of Coal Geology 35, 175-207.

Maughan, E.K., Perry Jr.., W.J., 1986. Lineaments and their tectonic implications in the Rocky Mountains and adjacent plains region, in: Peterson, J.A. (Ed.), Paleotectonics and Sedimentation in the Rocky Mountain Region, United States, pp. 41-53. AAPG Memoir 41.

McDonald, G.D., Paillet, F.L., Barton, C.C., Johnson, C.D., 1997. Borehole sampling of fracture populations-compensating for borehole sampling bias in crystalline bedrock aquifers, Mirror Lake, Grafton County, New Hampshire. International Journal Rock Mechanics Mining Science and Geomechanics Abstracts 34 (3-4), 239.

Meissner, R., 1986. The Continental Crust: A Geophysical Approach, International Geophysics Series 34. Academic Press, New York, p. 426.

Morin, R.H., 2000. Geophysical logging techniques used in the hydrogeologic characterization of sedimentary basins, Proceedings of 1st Joint IAH-CNC and CGS Groundwater Specialty Conference, Montreal, Canada, pp. 353-358.

Morin, R.H., Savage, W.Z., 2003. Effects of crustal stresses on fluid transport in fractured rock: case studies from northeastern and southwestern USA. Hydrogeology Journal 11, 100-112.

Morin, R.H., Newmark, R.L., Barton, C.A., Anderson, R.N., 1990. State of lithospheric stress and borehole stability at DSDP site 504B, eastern equatorial Pacific. Journal of Geophysical Research 95, 9293-9303.

Paillet, F.L., Cheng, C.H., 1991. Acoustic Waves in Boreholes. CRC Press, Boca Raton, Florida, p. 264.

Pollard, D.D., Aydin, A., 1988. Progress in understanding jointing over the past century. Geological Society of America Bulletin 100, 1181-1204.

Pratt, T.J., Mavor, M.J., DeBruyn, R.P., 1999. Coal gas resource and production potential of subbituminous coal in the Powder River Basin, Proceedings of International Coalbed Methane Symposium. University of Alabama, Tuscaloosa pp. 23-34.

Prucha, J.J., Graham, J.A., Nickelsen, R.P., 1965. Basementcontrolled deformation in Wyoming province of Rocky Mountains foreland. AAPG Bulletin 49 (7), 966-992.
Robinson, L.N., Barnum, B.E., 1986. Southeastern extension of the Lake Basin Fault Zone in south-central Montana: implications for coal and hydrocarbon exploration. The Mountain Geologist 23 (2), 37-44.

Rutqvist, J., Stephansson, O., 2003. The role of hydromechanical coupling in fractured rock engineering. Hydrogeology Journal 11 (1), 7-40.

Saulsberry, J.L., Schafer, P.S., Schraufnagel, R.A. (Eds.), 1996. A Guide to Coalbed Methane Reservoir Engineering GRI Reference No. GRI-94/0397. Gas Research Institute, Chicago, IL.

Saunders, D.F., Hicks, D.E., 1976. Regional geomorphic lineaments on satellite imagery-their origin and applications, in: Podwysocki, M.H., Earle, J.L. (Eds.), Proceedings of Second International Conference on Basement Tectonics, Newark, Delaware, pp. 326-352.

Savage, W.Z., Morin, R.H., 2002. Topographic stress perturbations in southern Davis Mountains, west Texas: 1. Polarity reversal of principal stresses. Journal of Geophysical Research 107 (B12), 2389.

Savage, W.Z., Swolfs, H.S., 1987. SLIP—a FORTRAN computer program for computing the potential for sliding on arbitrarily oriented weakness planes in triaxial stress states. U.S. Geological Survey Open-file Report, p. 93.

Sayers, C.M., 1990. Stress-induced fluid flow anisotropy in fractured rock. Transport Porous Media 5, 287-297.

Schumm, S.A., Dumont, J.F., Holbrook, J.M., 2000. Active Tectonics and Alluvial Rivers. Cambridge University Press p. 276.

Thomas, G.E., 1976. Lineament-block tectonics: North AmericaCordilleran Orogen, in: Podwysocki, M.H., Earle, J.L. (Eds.), Proceedings of Second International Conference on Basement Tectonics, Newark, Delaware, pp. 361-370.

Tyler, R., Laubach, S.E., Ambrose, W.A., Tremain, C.M., Grout, M.A., 1993. Coal fracture patterns in the foreland of the Cordilleran Thrust Belt, western United States, Proceedings of International Coalbed Methane Symposium. University of Alabama, Tuscaloosa pp. 695-704.

Van Krevelen, D.W., 1981. Coal: Typology-Chemistry-PhysicsConstitution. Elsevier, New York p. 514.

Weeks, E.P., 2004. Hydrologic properties of coal beds in the Powder River Basin, Montana II. Aquifer test analysis. Journal of Hydrology. Hydrol 14715 in this issue.

White, J.E., 1983. Underground Sound-Application of Seismic Waves. Elsevier, New York p. 253.

Wyoming Oil and Gas Conservation Commission, 2003. Statistics from web site http://wogcc.state.wy.us.

Zemanek, J., Glenn, E.E., Norton, L.J., Caldwell, R.L., 1970. Formation evaluation by inspection with the borehole televiewer. Geophysics 35, 254-269.

Zoback, M.L., Zoback, M.D., 1989. Tectonic stress field of the conterminous United States, in: Parker, L.C., Mooney, W.D. (Eds.), Geophysical Framework of North America, pp. 523-539. GSA Memoir 172.

Zoback, M.D., Moos, D., Mastin, L., Anderson, R.N., 1985. Well bore breakouts and in situ stress. Journal of Geophysical Research 90, 5523-5530. 